\title{
Alternative vibro-dynamic compression processing of wood-cement composites using Amazonian wood
}

\author{
Vinicius Gomes de CASTRO ${ }^{1 *}$, Rafael da Rosa AZAMBUJA², Carlos Frederico Alice PARCHEN ${ }^{3}$, Setsuo IWAKIRI ${ }^{4}$ \\ Universidade Federal Rural do Semi-Árido (UFERSA), Departamento de Ciências Agronômicas e Florestais, Av. Francisco Mota, 572, Costa e Silva, CEP 59625-900, \\ Mossoró, RN, Brasil \\ 2 West Virginia University, Davis College of Agriculture, Natural Resources and Design, , Morgantown, WV, USA \\ 3 Universidade Federal do Paraná (UFPR), Departmento de Construção Civil, Campus IV, Jardim das Américas, CEP 81531-980, Curitiba, PR, Brasil \\ ${ }^{4}$ Universidade Federal do Paraná (UFPR), Departmento de Engenharia e Tecnologia Florestal, Av. Lothário Meissner, 632, Jardim Botânico, CEP 80210-170, Curitiba, \\ PR, Brasil \\ * Corresponding author: vinicius.castro@ufersa.edu.br
}

\begin{abstract}
Wood-cement composite (WCC) is a potential construction material for tropical regions, due to its physico-mechanical properties and resistance to decay and fungi attack. However it is important to test alternative production methods and wood materials that are easier and cheaper than those traditionally used, in order to create a higher demand for this product. The aim of this work was to evaluate the use of wood from four Amazonian species (Eschweilera coriaceae, Swartzia recurva, Manilkara amazonica and Pouteria guianensis) in the production of wood-cement composites through a vibro-dynamic compression process, an alternative method to the use of a hydraulic press. The inhibition degree caused by the wood to the cement cure, measured by the factor $\mathrm{C}_{\mathrm{A}}$, indicated that all species were compatible with Portland cement (CP II-Z). WCC with densities higher than $1,100 \mathrm{~kg} \mathrm{~m}^{-3}$ (produced with $E$. coriaceae and $S$. recurva particles) showed compressive strength values higher than $10 \mathrm{MPa}$, which fulfills the minimum requirement for lightweitgh reinforced concrete blocks for structural use.
\end{abstract}

KEYWORDS: $\mathrm{C}_{\mathrm{A}}$ factor; Eschweilera coriaceae; Swartzia recurva; Manilkara amazonica; Pouteria guianensis

\section{Método alternativo de compactação vibro-dinâmica na produção de compósitos madeira-cimento com uso de madeiras amazônicas}

\section{RESUMO}

Compósito madeira-cimento é um potencial material de construção para regiôes tropicais, devido a suas propriedades físicomecânicas e resistência ao ataque de fungos e podridão. Contudo, é importante testar métodos alternativos de produção e madeiras que sejam mais simples e baratos do que os tradicionalmente usados, para que se alcance uma maior demanda para esse produto. O objetivo deste estudo foi avaliar o uso de madeira de quatro espécies amazônicas (Eschweilera coriaceae, Swartzia recurva, Manilkara amazonica e Pouteria guianensis) na produção de compósitos de madeira-cimento (WCC) pelo processo de compactação vibro-dinâmica, um método alternativo que dispensa o uso de prensas hidráulicas. $\mathrm{O}$ grau de inibição à pega do cimento causado pela presença da madeira foi medido pelo fator $\mathrm{C}_{\mathrm{A}}$ e indicou que todas as quatro espécies foram compatíveis com o cimento Portland (CP II-Z). Compósitos com massa específica superior a $1.100 \mathrm{~kg} \mathrm{~m}^{-3}$ (produzidas com partículas de E. coriaceae e $S$. recurva) apresentaram valores de compressão axial acima de $10 \mathrm{MPa}$, requisito mínimo para classificar como blocos de concreto reforçados leves de uso estrutural.

PALAVRA-CHAVE: fator $\mathrm{C}_{\mathrm{A}}$; Eschweilera coriaceae; Swartzia recurva; Manilkara amazonica; Pouteria guianensis

\section{INTRODUCTION}

In 2015, the legal log extraction in the Brazilian Amazonian region was of nearly 11.4 million $\mathrm{m}^{3}$, and the wood industry in the region generated a raw income of $\mathrm{R} \$ 1.9$ billion (about USD 475 million) (SFB 2017). However, the average yield of processing wood was $41 \%$, of which $9 \%$ was burned and $16 \%$ was thrown away as refuse (Pereira et al. 2010). In some cases these numbers can be even higher, as reported for sawmills in Rorainópolis (Roraima state, in the northern Brazilian Amazon) where $80 \%$ of residue wood is burnt (Dias et al. 2015). It follows from these figures that the Brazilian Amazon wood industry produces a high amount of waste, that is not properly recovered.

Wood-cement composite (WCC) is a potential solution for the problem of the poorly managed refused wood as it can 
use slabs, offcuts or cantlings as raw materials. WCC provides a wide range of products for building applications, due to its mechanical properties, dimensional stability, acoustic and thermal insulation, fire resistance and good workability (Latorraca and Iwakiri 2005). In tropical regions, the use of WCC can be even more attractive to construction, as it provides resistance to decay and fungi attacks, common in warm and humid climate, and also satisfies the cultural preference for cement-based materials, while attending to health and safety requirements (Ramirez-Coretti et al. 1998).

WCCs are traditionally produced by the BISON method, developed and licensed by the German company Bisonwerke. Mixtures of $62 \%$ cement, $28 \%$ wood and $10 \%$ water are pressed to form panels with density around $1,250 \mathrm{~kg} \mathrm{~m}^{-3}$ (NCL Industries 2011). However, this method requires a high initial investment, once it is necessary to purchase expensive equipments, such as a hydraulic plate press. Seeking a more economically viable alternative, Parchen et al. (2016) suggested the use of vibro-dynamic compression. The vibro-compaction process is already employed for the construction of buildings with reinforced concrete structures (Neville and Brooks 2010). The WCC densification is based on an eccentric load on a rotating axis that creates a dynamic vibration. The load can be produced by a cheap and easy-to-purchase electric vibrator, that can be assembled in a vibrating table made of plywood, a simple piece of equipment that is easy to install and operate (Neville and Brooks 2010). Thus, this new process has a great potential to be used in small production units attached to already functional small sawmills, as are found in the Amazonian region, allowing for in loco processing of wood as raw material for local social housing.

Therefore, the aim of this work was to evaluate the physical and mechanical properties of WCC produced using vibro-dynamic compression with slabs from four different Amazonian timber species.

\section{MATERIAL AND METHODS}

Slabs were obtained from logs sawn at a sawmill located in Manaus, Amazonas state, Brazil. Four tropical timber species were evaluated as raw material for WCC production: Eschweilera coriaceae (A. DC. Mori.) (density $730 \mathrm{~kg} \mathrm{~m}^{-3}$ ), Swartzia recurva Poepp. (800 kg m$\left.{ }^{-3}\right)$, Manilkara amazonica (Huber) $(800 \mathrm{~kg}$ $\left.\mathrm{m}^{-3}\right)$, and Pouteria guianensis Aubl $\left(680 \mathrm{~kg} \mathrm{~m}^{-3}\right)$.

The selected trees were harvested and processed by bandsaw. The slabs were collected and stored during a period of nearly a year. Aiming to reduce the extractive content from the material, the slabs were cut down to smaller pieces and submerged in cold water during 7 days before being converted into particles. During the soaking period, the water was changed daily to avoid saturation. Particles generated in a disk chipper were then kiln dried to a moisture content of approximately $3 \%$ and reprocessed in a hammermill. After milling, the particles were classified by automatic sieving.

The compatibility $C_{A}$ factor (Hachmi and Moslemi 1989) was used for the hydration test. The test equipment consisted of type J thermocouples with channels connected to an analog signal conditioning module coupled to an analog-to-digital conversion board. Wood particles that passed through the 20 mesh sieve and retained at the 35 mesh sieve (15 g dry weight) were dry mixed with Type II commercial Portland cement (CP II-Z) $(200 \mathrm{~g})$ in a polyethylene bag, and received $90.5 \mathrm{~mL}$ of water $(2.7 \mathrm{~mL}$ of water per gram of dry wood and an additional $0.25 \mathrm{~mL}$ per gram of cement). The control (containing only cement and no wood) used $40 \mathrm{~mL}$ of water.

Immediately after mixing the cement and wood, the tip of the temperature thermocouple was enclosed within the body of the wood-cement mixtures that were placed in a thermo flask. The heat of hydration was recorded over a 24 -h period at 1-min intervals. Three repetitions were used for each species and the control to determine the compatibility between the materials. Species were classified based on the average value of the $\mathrm{C}_{\mathrm{A}}$ factor as 'compatible', $\mathrm{C}_{\mathrm{A}}>68 \%$; 'moderately compatible', $28 \%<\mathrm{C}_{\mathrm{A}}<68 \%$; and 'not compatible, $\mathrm{C}_{\mathrm{A}}<$ 28\% (Hachmi and Moslemi 1989).

For WCC production we used the wood particles retained between the 8 and 14 mesh sieves. WCC were produced by the vibro-dynamic compaction method suggested by Parchen et al. (2016). Portland CP II-Z was used with a wood:cement ratio of 1:2.75, based on oven dry weight. The amount of water used in the mixture was determined by an adjustment to the formula suggested by Simatupang (1979) for the production of traditional WCC $(0.5 \mathrm{ml}$ of water for every gram of cement and an additional $0.3 \mathrm{ml}$ for every gram of wood, based on oven dry weight). Three percent of calcium chloride $\left(\mathrm{CaCl}_{2}\right)$, based on cement weight, was added to the mixture as cement accelerator.

The mixtures were deposited on marine plywood prismatic molds $(420 \times 70 \times 15 \mathrm{~mm}$ ) (Figure 1). An equivalent impact load of $220 \mathrm{~N}$ at $3000 \mathrm{rpm}$ was applied to the composite material in their freshly molded state for 30 seconds. During this time period, densification of the material occurred. The prismatic mold was refilled with an extra amount of material and submitted again to 30 seconds of vibration. This process was repeated until there was no free space available in the mold, even after an extra vibration period. The specimens were kept in the molds for 7 days. After this period, the molds were disassembled and the WCC remained in an outdoor environment until reaching the cure period of 28 days prior to the performance tests.

The samples were cut to the dimensions of the European Standard. Sample size per species for mechanical and physical evaluation was eight specimens of $50 \times 15 \times 350 \mathrm{~mm}$ for static bending strength (MOR and MOE) (ECS 1993a), six 


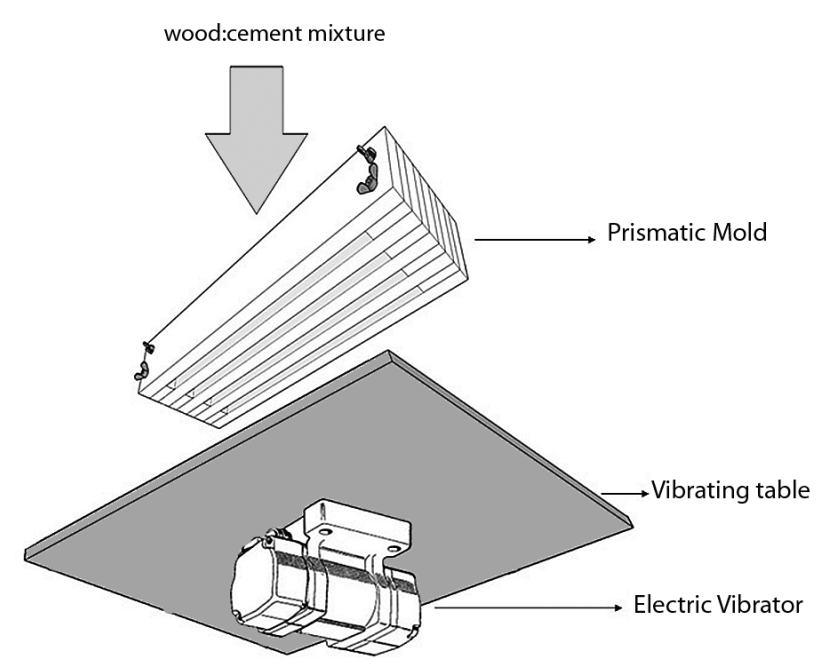

Figure 1. Scheme of the WCC forming process using a prismatic mold and a vibrating table. Author: Vinicius Gomes de Castro, with elements adapted from $<$ http://www.wuerges.de>.

specimens of $50 \times 50 \times 15 \mathrm{~mm}$ for water absorption (WA) and thickness swelling, measured at two and 24 hours of immersion (ECS 1993b), and eight specimens of 50 x 50 x $15 \mathrm{~mm}$ for internal bonding (ECS 1993c). Seven cylindrical specimens ( $40 \mathrm{~mm}$ in diameter and $80 \mathrm{~mm}$ in height) were produced for each species to evaluate compressive strength according to the Brazilian Standard (ABNT 1996). The compaction ratio was calculated based on the relation between the composite final density and the density of the wood used in its composition.

Data normality was assessed through skewness and kurtosis tests. Variables with normal distribution were assessed with the Box-Cox method to select the fitting transformation parameter $\lambda$ for each case. Normalized values of the $C_{A}$ factor and the variables of physical and mechanical properties of the WCCs were analyzed with Analysis of Variance (ANOVA) followed by the Tukey test (at the 5\% significance level). Pearson's correlation was used to assess the relation between physical and mechanical properties of the WCCs and the original characteristics of the wood (wood density, $\mathrm{C}_{\mathrm{A}}$ factor and arabinose content). Arabinose content values for the study species were retrived from Castro et al. (2017). All statistical analyses were carried out with the Statgraphics Centurion XV software.

\section{RESULTS}

All wood-cement mixtures showed mean values of the compatibility $\mathrm{C}_{\mathrm{A}}$ factor above 68 (Figure 2), and were thus suitable for the production of WCC. The WCC densities varied from 1060 to $1230 \mathrm{~kg} \mathrm{~m}^{-3}$, leading to composite compaction ratios of 1.4 to 1.5 , with the exception of WCC of $E$. coriaceae, which had the highest ratio at 1.7 (Table 1). Nominal composite density varied according to original wood density.

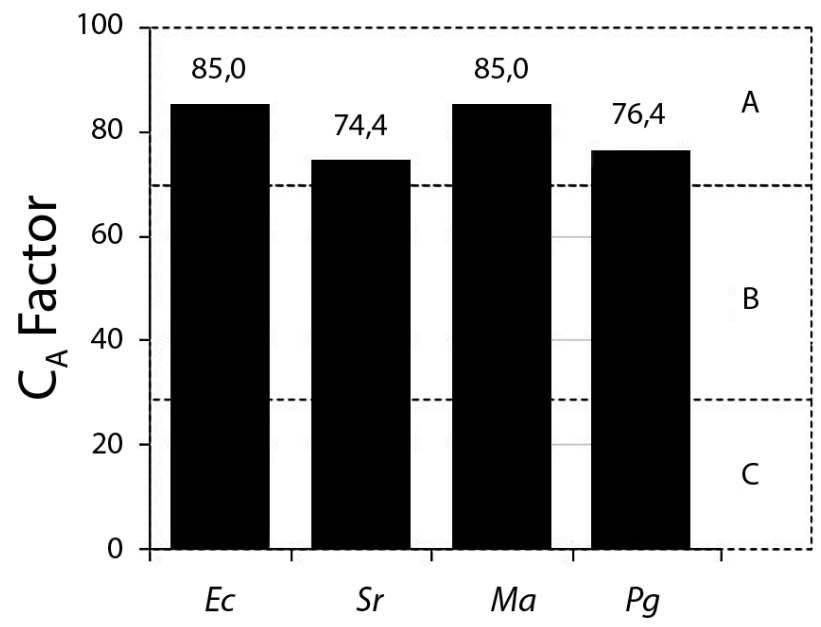

Figure 2. Compatibility $C_{A}$ factor for four Amazonian timber species. $A=$ compatible; $\mathrm{B}=$ moderately compatible; $\mathrm{C}=$ not compatible; $E \mathrm{C}=$ Eschweilera coriaceae; $\mathrm{Sc}=$ Swartzia recurva; $\mathrm{Ma}=$ Manilkara amazonica; $\mathrm{Pg}=$ Pouteria guianensis. Values above the columns are the specific $C_{A}$ factor measured for the species.

There was a statistically significant difference between water absorption after two hours and after 24 hours of immersion for $P$. guianensis (the lightest composite) (19.8\% and $22.3 \%$, respectively) and $M$. amazonica composites (13.6\% and $15.2 \%$, respectively). Thickness swelling did not vary significantly among the species, all remaining below $1 \%$ after two hours, and below $1.5 \%$ after 24 hours of immersion, which is considered acceptable for commercial WCC according to the BISON requirements (NCL Industries 2011) (Table 1).

There was no statistically significant difference in internal bonding and compression strength among the species (Figure 3). With the exception of Manilkara amazonica composites, all WCCs had average internal bonding values that met the minimum requirement of $0.4 \mathrm{MPa}$ suggested for commercial wood-cement panels produced by the BISON process (NCL Industries 2011). Compressive strength of WCC produced with $E$. coriaceae and $S$. recurva attended the minimum requirement of Brazilian standard NBR 8953 for materials of the C10 class I for concrete (ABNT 2009). B e $\mathrm{n} d$ i $\mathrm{n} g$ strength was significantly higher for $E$. coriaceae (3.7 MPa) than for $P$. guianensis WCCs (2.7 MPa).

MOE values of $P$. guianensis WCCs $(1,669 \mathrm{MPa})$ differed significantly from those of $E$. coriaceae and $S$. recurva, $(2,873$ and 2,631 MPa, respectively). None of the composites reached the minimum requirement of $9 \mathrm{MPa}$ for MOR and 3,000 MPa MOE for WCC produced by the traditional press method (NCL Industries 2011). The WCC produced with E. coriaceae had a mean value of MOE close to the minimum requirement $(2,873 \mathrm{MPa})$.

There was no correlation between the compatibility $\mathrm{C}_{\mathrm{A}}$ factor and the physico-mechanical properties of the WCCs, but wood density and arabinose content correlated significantly with some properties of the WCC (Table 2). 
Table 1. Physical properties of vibro-dynamic wood-cement composites (WCCs) made from residues of four Amazonian timber species. Values are means followed by the coefficient of variation (\%) in parentheses. Different letters following the variable mean in each line indicate significant differences according to the Tukey test $(p<0.05)$.

\begin{tabular}{|c|c|c|c|c|}
\hline $\begin{array}{l}\text { Density }\left(\mathrm{kg} \mathrm{m}^{-3}\right) \\
\text { Compaction ratio }\end{array}$ & $\begin{array}{c}\text { Eschweilera coriaceae } \\
1230(4.23)^{\mathrm{a}} \\
1.68\end{array}$ & $\begin{array}{c}\text { Swartzia recurva } \\
1140(4.52)^{b} \\
1.43\end{array}$ & $\begin{array}{c}\text { Manilkara amazonica } \\
1170(4.88)^{\mathrm{b}} \\
1.46\end{array}$ & $\begin{array}{c}\text { Pouteria guianensis } \\
1060(1.96)^{c} \\
1.48\end{array}$ \\
\hline Water absorption $2 \mathrm{~h}(\%)$ & $14.76(7.31)^{\mathrm{ab}}$ & $16.69(6.98)^{\mathrm{ab}}$ & $13.62(6.66)^{b}$ & $19.79(7.58)^{\mathrm{a}}$ \\
\hline Water absorption 24 h (\%) & $17.13(8.23)^{a b}$ & $19.43(5.46)^{\mathrm{ab}}$ & $15.20(5.27)^{b}$ & $22.28(5.59)^{\mathrm{a}}$ \\
\hline Thickness swelling 2 h (\%) & $0.22(47.67)^{\mathrm{a}}$ & $0.36(52.83)^{\mathrm{a}}$ & $0.26(35.10)^{\mathrm{a}}$ & $0.30(66.74)^{\mathrm{a}}$ \\
\hline Thickness swelling $24 \mathrm{~h}(\%)$ & $0.30(47.29)^{\mathrm{a}}$ & $0.45(27.74)^{\mathrm{a}}$ & $0.33(28.59)^{a}$ & $0.41(49.07)^{a}$ \\
\hline
\end{tabular}

Table 2. Correlation between physical and mechanical properties of vibro-dynamic wood-cement composites (WCC) made from four Amazonian timber species (Eschweilera coriaceae, Swartzia recurva, Manilkara amazonica and Pouteria guianensis).

\begin{tabular}{|c|c|c|c|c|}
\hline & \multicolumn{3}{|c|}{ Original wood properties } & \multirow{2}{*}{ Composite density } \\
\hline & $C_{A}$ Factor & Wood density & Arabinose content & \\
\hline Composite density & $0.2977(0,4739)$ & $0.8080(0.0152)^{*}$ & $0.2133(0.6120)$ & - \\
\hline Water absorbtion $2 \mathrm{~h}$ & $-0.4185(0,3021)$ & $-0.8519(0.0072)^{*}$ & $-0.1274(0.7638)$ & $-0.9561(0.0002)^{*}$ \\
\hline Water absorbtion $24 \mathrm{~h}$ & $-0.4608(0.2505)$ & $-0.8293(0.0109)^{*}$ & $-0.1174(0.7819)$ & $-0.9457(0.0004)^{*}$ \\
\hline Thickness swelling $2 \mathrm{~h}$ & $-0.1079(0.7993)$ & $0.6215(0.1000)$ & $0.7724(0.0247)^{*}$ & $0.5735(0.1372)$ \\
\hline Thickness swelling $24 \mathrm{~h}$ & $-0.1704(0.6867)$ & $-0.3942(0.3339)$ & $0.7192(0.0444)^{*}$ & $-0.3299(0.4249)$ \\
\hline Internal bonding & $-0.3747(0.3604)$ & $-0.1930(0.6470)$ & $0.7581(0.0293)^{*}$ & $-0.0343(0.9357)$ \\
\hline MOR & $0.3235(0.4344)$ & $0.4599(0.2515)$ & $0.3964(0.3310)$ & $0.7920(0.0191)^{*}$ \\
\hline MOE & $0.2585(0.5365)$ & $0.7427(0.0348)^{*}$ & $0.4196(0.3007)$ & $0.9505(0.0003)^{*}$ \\
\hline Compression resistance & $0.2531(0.5453)$ & $0.6139(0.1054)$ & $0.2025(0.6305)$ & $0.9245(0.0010)^{*}$ \\
\hline
\end{tabular}

$\mathrm{MOR}=$ Modulus of Rupture in bending; $\mathrm{MOE}=$ Modulus of Elasticity in bending; $\mathrm{C}_{\mathrm{A}}$ Factor = compatibility ratio between wood and cement; Values are the correlation coefficient, followed by the $\mathrm{P}$-value in parentheses. ${ }^{*}$ indicates significant correlations at $\mathrm{P}<0.05$.

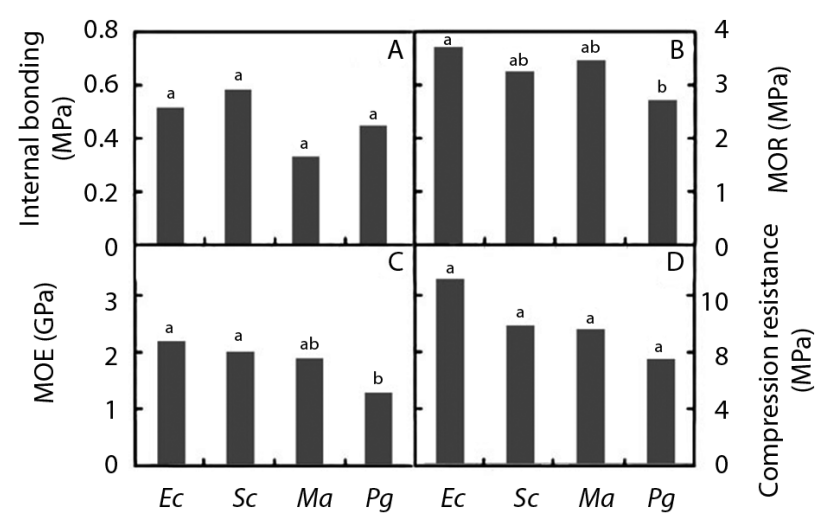

Figure 3. Mechanical properties of vibro-dynamic wood-cement composites (WCC) made from four Amazonian timber species. Different letters above columns within graphs indicate statistically significant differences according to the Tukey test $(p<0.05)$. Ec $=$ Eschweilera coriaceae; $S c=$ Swartzia recurva; $M a=$ Manilkara amazonica; $\mathrm{Pg}=$ Pouteria guianensis.

\section{DISCUSSION}

The inhibition effect that timber has on Portland cement hardening is not yet fully understood, but it is known that the material compatibility is primarily affected by the presence of extractives, part of hemicelluloses and their degradation products ( $\mathrm{Na}$ et al. 2014). Tropical species tend to present high contents of extractives and, for this reason, are often overlooked as WCC raw material. Our study species have high total extractive contents, between $9.2 \%$ and $16.2 \%$ (Castro et al., 2017). The high degree of compatibility found can be explained in part by the part of the tree trunk from where the wood samples were collected. The wood from slabs, the outer part of the trunk, is almost totally formed by sapwood, which tends to have a lower degree of inhibition on cement than heartwood (Cabongon et al. 2002; Semple and Evans 2000).

Values of water absorption in our WCC samples were lower than those reported for traditionally pressed WCC with similar density produced with Amazonian timber species (Cedrela odorata, Hymenaea courbaril and Vochysia maxima) (Macedo et al. 2012), and much lower than those in WCCs produced with Eucalyptus saligna using vibro-dynamic compaction (Castro et al. 2015). A compaction ratio of 1.3 is ideal for particleboards, as values bellow 1.3 indicate a lower degree of compaction, leading to boards having mechanical problems (Iwakiri et al. 2005). To ensure the necessary densification, manufacturing usually uses low density wood (Iwakiri et al. 2005). In our study, the vibro-compaction method was efficient, considering that compaction ratios were higher than 1.3 even using high density woods.

Water absorption was related to the final WCC density, i.e. the heavier the composite, the lower the water absorption capacity. In this case, it is important to notice a specific characteristic of vibro-dynamic compaction that differs from the traditional press method: the final WCC density is directly 
determined by the wood particle density. Without pressure, the volume of material deposited into the mold cannot be predetermined simply by weight, thus the amount of the mixture that will form the composite depends on the particle size and density used as raw material (Castro et al. 2015).

Our WCC samples had higher internal bonding than WCC produced with Pinus spp at a wood:cement ratio of 1:1 using a similar method and densities (Parchen et al. 2016), but lower bonding than vibro-compacted, similar density WCC produced with Pinus taeda at a wood:cement ratio of 1:4 (Castro and Iwakiri 2014). Our WCC samples also had higher MOR and MOE values than composites produced with Eucalyptus saligna (Castro et al. 2015) and Pinus spp (Parchen et al. 2016; Azambuja et al. 2017). Composites produced with E. coriaceae had similar MOR to WCC produced with the traditional press method with Hymenaea courbaril, another Amazonian timber species, (Macedo et al. 2012).

The WCCs produced with E. coriaceae and S. recurva had compressive strength values that attended the minimum requirements of the Brazilian standard NBR 8953 for materials of the group C10 class I for concrete (ABNT 2009). Compressive strength values in the four species tested were higher than those reported for vibro-compacted WCC made of Pinus spp with a wood:cement ratio of 1:1 (Parchen et al. 2016) and 1:1.5 (Villas-Bôas et al. 2017). The E. coriaceae and $S$. recurva composites also showed higher strength and were lighter than plant-reinforced concrete blocks (cementitious matrix with wood fiber waste and rice husk ash replacement) that had strength values of 1 and $7 \mathrm{MPa}$ and density between 1400 and $1900 \mathrm{~kg} \mathrm{~m}^{-3}$ (Torkaman et al. 2014).

\section{CONCLUSIONS}

The wood from four Amazonian timber species was viable as raw material for production of wood-cement composites using vibro-dynamic compression. All studied species had $\mathrm{C}_{\mathrm{A}}$ factor values within the compatibility range in mixture with Portland cement. The hydration test indicated that the wood had no inhibitory effect on the final physical and mechanical properties of the wood-cement mixture after the 28 day cement cure period. The physical and mechanical properties of the WCCs produced for this study were better than those reported for other vibro-compacted WCCs, although the mechanical properties of our wood cement boards did not attain the minimal requirements for pressed products. However the vibro-compacted WCCs produced with Eschweilera coriaceae and Swartzia recurva showed potential for use as reinforced lightweight concrete blocks, since they attained the minimun requirements to be recommended as concrete for structural purposes.

\section{ACKNOWLEDGMENTS}

The authors express their gratitude Conselho Nacional de Desenvolvimento Científico e Tecnológico (CNPq) and Instituto Nacional de Pesquisas da Amazônia (INPA), through the Instituto Nacional de Ciência e Tecnologia de Madeiras da Amazônia (INCT Madeiras da Amazônia) for granting the raw material of this research.

\section{REFERENCES}

ABNT. 1996. Associação Brasileira de Normas Técnicas, NBR 7215. Cimento Portland - Determinação da resistência à compressão.

ABNT. 2009. Associação Brasileira de Normas Técnicas, NBR 8953. Concretos para fins estruturais - Classificação por grupos de resistência.

Azambuja, R.R.; Castro, V.G.; Villas-Bôas, B.T.; Parchen, C.F.; Iwakiri, S. 2017. Particle size and lime addiction on properties of wood-cement composites produced by the method of densification by vibro compaction. Ciência Rural, 47: e20140250.

Cabangon, R.J.; Eusebio, D.A.; Sotiano, F.P.; Cunningham, R.B.; Donnely, C.; Evans, P.D. 2002. Effect of post-harvest storage on the suitability of Acacia mangium for the manufacture of woodwool cement boards. In: Evans, P.D. Wood-cement composites in the Asia-Pacific region. ACIAR, Camberra, p.97-104.

Castro, V.; Iwakiri, S. 2014. Influência de diferentes níveis de acetilação nas propriedades físico-mecânicas de aglomerados e painéis madeira-cimento. Cerne, 20: 535-540.

Castro, V.G.; Braz, R.L.; Azambuja, R.R.; Loiola, P.L.; Iwakiri, S.; Matos, J.L.M. 2015. Painéis cimento-madeira de Eucalyptus saligna com diferentes aditivos químicos e métodos de formação. Floresta, 25: 349-360.

Castro, V.G.; Azambuja, R.R.; Bila, N.F.; Parchen, C.F.A.; Sassaki, G.L.; Iwakiri, S. 2017. Correlation between chemical composition of tropical hardwoods and wood-cement compatibility. Journal of Wood Chemistry and Technology, 37: 1-7.

Dias, J.A.; Santos, C.M.L.; Condé, T.M. 2015. A contabilidade ambiental no aproveitamento de resíduos madeireiros em Rorainópolis-RR. Revista Remgads, 8: 17-22.

ECS. 1993a. European Committee for Standardization. EN 310. Wood-based panels - Determination of modulus of elasticity in bending and of bending strength.

ECS. 1993b. European Committee for Standardization. EN 317. Aglomerado de partículas de madeira e aglomerado de fibras de madeira - Determinação do inchaço na espessura depois da imersão em água.

ECS. 1993c. European Committee for Standardization. EN 319. Aglomerado de partículas de madeira e aglomerado de fibras de madeira - determinação da força da tensão perpendicular sobre a superfície plana da placa.

Hachmi, M.; Moslemi, A.A. 1989. Correlation between woodcement compatibility and wood extractives. Forest Products Journal, 39: 55-58. 
Iwakiri, S.; Albuquerque, C.E.C.; Mendes, L.M.; Latorraca, J.V. 2005. Painéis de madeira aglomerada. In: Iwakiri, S. Painéis de madeira reconstituida. FUPEF, Curitiba. p.123-166.

Latorraca, J.V.; Iwakiri, S. 2005. Painéis de madeira-cimento. In: Iwakiri, S. Painéis de madeira reconstituida. FUPEF, Curitiba. p.213-254.

Macedo, A.N.; Souza, A.A.C.; Pompeu Neto, B.B. 2012. Chapas de cimento-madeira com resíduos da indústria madeireira da regiáo amazônica. Ambiente Construído, 12: 131-150.

Na, B.; Wang, Z.; Wang, H.; Lu, X. 2014. Wood-cement compatibility review. Wood Research, 59: 813-826.

NCL Industries. 2011. Bison panel-Cement bonded particle board. Abids. 24p.

Neville, A.M.. Brooks, J.J. 2010. Concrete technology. 2nd ed. Pearson, Harlow. 442p.

Parchen, C.F.A.; Iwakiri, S.; Zeller, F.; Prata, J.G. 2016. Vibrodynamic compression processing of low-density wood-cement composites. European Journal of Wood and Wood Products, 74: 75-81.

Pereira, D.; Santos, D.; Vedoveto, M.; Guimarães, J.; Veríssimo, A. 2010. Fatos florestais da Amazônia. IMAZON, Belém. 124p.

Ramirez-Coretti, A.; Eckelman, C.A. Wolfe, R.W. 1998. Inorganicbonded composite wood panel systems for low-cost housing: a central American perspective. Forest Products Journal, 48: 62-68.
Semple, K.; Evans, P.D. 2000. Adverse effects of heartwood on the mechanical properties of wood-wool cement boards manufactured from radiata pine wood. Wood and Fiber Science, 32: 37-43.

SFB. 2017. Serviço Florestal Brasileiro. Plano anual de outorga florestal 2018. SFB, Brasília. 116p.

Simatupang, M.H. 1979. Der wasserbedarf bei der Herstellung zementgebundener Holzspanplatten. Holz als Rouh-und Werkstoff, 37: 379-382.

Torkaman, J.; Ashori, A.; Momtazi, A.S. 2014. Using wood fiber waste, rice husk ash, and limestone powder waste as cement replacement materials for lightweight concrete blocks. Concrete and Building Materials, 50: 432-436.

Villas-Bôas, B.T.; Parchen, C.F.A.; Iwakiri, S.; Prata, J.G.; Costa, M.R.M.M. 2017. Avaliação dos efeitos de diferentes dosagens de água/cal na resistência à compressão axial de compósitos de madeira-cimento. Revista Matéria, 21: e11777.

RECEIVED: $18 / 01 / 2018$

ACCEPTED: 09/08/2018

ASSOCIATE EDITOR: João Vicente Souza 